\title{
Response to cold exposure of three cattle breeds with different adaptation capacities
}

\author{
M Derno, W Jentsch, HD Matthes, B Löhrke \\ Research Institute for the Biology of Farm Animals Dummerstort-Rostock, Department of Nutritional \\ Physiology "Oskar Kellner", 18059 Rostock, Germany
}

\begin{abstract}
Research on mechanisms of animals adaptation to cold includes investigations on physiological reactions, on the morphology of the body and on the energy metabolism. In order to investigate the interaction of these components of the adaptation capacity, a series of experiments was carried out with growing bulls $(250-370 \mathrm{~kg})$ of the breeds Galloway (Ga), Highland (Hi) and Black White dairy Cattle (BW) which served as a model of different adaptive types of cattle.
\end{abstract}

In 15 trials the energy metabolism of $8 \mathrm{Ga}, 8 \mathrm{Hi}$ and $16 \mathrm{BW}$ bulls was measured with different rations including varying nutrition levels. There were no differences in digestion capacity and diet metabolizability. The maintenance energy requirement $\left(\mathrm{ME}_{m}\right)$ of $\mathrm{Ga}$ and $\mathrm{Hi}$ bulls determined by energy balance trials was not significantly different but about $19 \%$ lower than that of BW bulls ( $n=8$, series 1) (Ga : $356 \pm 65, \mathrm{Hi}: 381 \pm 28$, BW1 : $439 \pm 64$, BW2 : $379 \pm 36 \mathrm{~kJ} / \mathrm{kg}^{0.75 \mathrm{~d}}$; Jentsch et al, 1995, Arch Anim Nutr, in press). In consequence of their lower heat production (HP), stronger metabolic reactions to exposure to lower ambient temperatures could be expected in $\mathrm{Hi}$ and $\mathrm{Ga}$ bulls.

All investigations were made in climatized respiration chambers. The animals were single kept and fed with a diet consisting of $20 \%$ barley and $80 \%$ hay (24\% crude fibre, $15 \%$ crude protein) at a nutrition level of $1.5 \mathrm{ME}_{\mathrm{m}}$. HP was determined by indirect calorimetry.

In the trials including short time (2 days), as well as with long time (12 days) exposure to temperatures $(\mathrm{T})$ of $4^{\circ} \mathrm{C}$, a $15 \%$ increase in HP in comparison to $18^{\circ} \mathrm{C}$ was found only in $\mathrm{BW}$ bulls. HP of $\mathrm{Hi}$ bulls at $4^{\circ} \mathrm{C}$ did not differ from $\mathrm{HP}$ at $18^{\circ} \mathrm{C}$ over 12 days, whereas HP of $\mathrm{BW}$ bulls increased on the second day and then remained at this level. To determine the insulation capacity of the hair coat, $\mathrm{Hi}$ and $\mathrm{BW}$ bulls were exposed to artificial rain at a rate of 20 l/animal per day at $4,12,18^{\circ} \mathrm{C}$ (2 days in each case, $\mathrm{T}$ of $\mathrm{H}_{2} \mathrm{O}: 8^{\circ} \mathrm{C}$ ). The daily $\mathrm{HP}$ was not influenced by the wet hair coat. In contrast unshorn and shorn $\mathrm{Hi}$ and $\mathrm{BW}$ bulls exposed at 18 and $4^{\circ} \mathrm{C}$ for 4 days showed significant thermoregulatory responses. Shearing led to an increase in HP in both types of animals after lowering the temperature to $4^{\circ} \mathrm{C}$ (table). However, the extent of this increase was higher in BW than in $\mathrm{Hi}$ bulls although the unshorn body was less insulated by the hair coat, suggesting that the difference in the thermoregulatory reactions between different adaptive types of cattle to cold is caused not only by the insulating capacity of the hair coat but also by the central nervous regulation of adaptation.

\begin{tabular}{|c|c|c|c|c|}
\hline $\mathrm{HP}\left(\mathrm{kJ} / \mathrm{kg} \mathrm{W}^{0.75 \mathrm{~d})}\right.$ & BW (unshorn) & BW(shorn) & Hi (unshorn) & Hi (shorn \\
\hline $\begin{array}{l}18^{\circ} \mathrm{C} \\
4^{\circ} \mathrm{C}\end{array}$ & $\begin{array}{l}623 \pm 28^{a} \\
654 \pm 51^{a}\end{array}$ & $\begin{array}{l}656 \pm 43^{a} \\
792 \pm 53^{b}\end{array}$ & $\begin{array}{l}533 \pm 52^{c} \\
573 \pm 25^{c}\end{array}$ & $\begin{array}{l}593 \pm 32^{c} \\
681 \pm 47^{d}\end{array}$ \\
\hline
\end{tabular}

Values with different superscripts differ significantly $(P<0.01)$ 